\title{
Survei Motivasi Siswa dalam Mengikuti Kegiatan Ekstrakurikuler Futsal di SMAN 1 Srengat Kabupaten Blitar
}

\author{
Miqdad Asykarillah*, Eko Hariyanto \\ Universitas Negeri Malang, Jl. Semarang No. 5 Malang, Jawa Timur, Indonesia \\ *Penulis korespondensi, Surel: asykarillah99@gmail.com
}

Paper received: 23-7-2021; revised: 13-8-2021; accepted: 20-8-2021

\begin{abstract}
This study aims to find out the amount of interest or motivation of students towards futsal extracurricular activities in SMAN 1 Srengat students. In this research used research method in the form of qualitative descriptive research method. The population in this study was 30 male students at SMAN 1 Srengat. The data collection stage uses a structured or closed questionnaire with a selection of answers using a Likert scale with a scale of one to 4 . The instrument used in this study is descriptive quantitative instrument. Based on the results of descriptive analysis, 53.3 percent of students want to show their existence by practicing in advance about the material to be taught, 86.67 percent of students strongly agree that extracurricular futsal can eliminate saturated effects, 60 percent of students strongly agree if coaches in extracurricular futsal provide interesting learning for students, and 53.33 percent of students choose this activity outside the classroom. As for the advice for coaches is to continue to increase student motivation, hard efforts need to be done by coaches in order to foster intrinsic motivation in students. This can be done by improving the pattern practicing futsal or doing something else that can foster intrinsic motivation to be more active in practicing.
\end{abstract}

Keywords: survey; futsal; motivation

\begin{abstract}
Abstrak
Penelitian ini bertujuan untuk mengetahui besarnya minat atau motivasi siswa terhadap kegiatan ekstrakurikuler futsal pada siswa SMAN 1 Srengat. Dalam penelitian ini digunakan metode penelitian berupa metode penelitian deskriptif kualitatif. Populasi pada penelitian ini adalah 30 siswa laki-laki di SMAN 1 Srengat. Tahap pengumpulan data menggunakan angket terstruktur atau tertutup dengan pilihan jawaban menggunakan skala Likert dengan skala satu sampai 4. Pada tahap pengumpulan data digunakan instrument kuantitatif deskriptif. Berdasarkan hasil analisis deskriptif, 53,3 persen siswa ingin menunjukan eksistensi dirinya dengan cara berlatih terlebih dahulu tentang materi yang akan diajarkan, 86,67 persen siswa sangat setuju jika ekstrakurikuler futsal dapat menghilangkan efek jenuh, 60 persen siswa sangat setuju jika pelatih dalam ekstrakurikuler futsal memberikan pembelajaran yang menarik bagi siswa, dan 53,33 persen siswa memilih kegiatan ini dilakukan diluar kelas. Adapun saran untuk pelatih adalah harus terus meningkatkan motivasi siswa, usaha keras perlu dilakukan oleh pelatih dalam rangka menumbuhkan motivasi intrinsik dalam diri siswa. Hal tersebut dapat dilakukan dengan cara meningkatkan pola latihan dalam berlatih futsal ataupun melakukan suatu hal lain yang dapat menumbuhkan motivasi intrinsik agar lebih giat dalam berlatih.
\end{abstract}

Kata kunci: survei; futsal; motivasi

\section{Pendahuluan}

Dunia olahraga yang saat ini berkembang pesat diharapkan dapat difungsikan untuk mencapai prestasi tinggi juga dapat menjadikan ajang rekreasi atau hiburan bahkan juga sarana terapi dan media pendidikan. Suatu aspek yang tidak bisa dihindari eksistensinya dalam kehidupan adalah pendidikan, sesuai dengan Undang-Undang Nomor 20 tahun 2003 bagian Pendidikan Nasional menyatakan bahwasanya pendidikan adalah usaha yang dilakukan secara sadar dan terencana dalam mewujudkan kegiatan pembelajaran dengan aktif melalui pengembangan potensi diri agar memiliki kekuatan keagamaan, pengendalian diri, kepribadian, 
kecerdasan, perilaku mula dan keterampilan yang dibutuhkan ketika terjun dalam bermasyarakat, berbangsa dan bernegara. Bagian penting dari proses pendidikan adalah pendidikan jasmani. Pendidikan jasmani dapat mengembangkan keterampilan hidup sehat. Hal tersebut menyatakan bahwa pendidikan jasmani, olahraga dan kesehatan merupakan suatu media dalam mendukung peningkatan kebugaran jasmani, pengetahuan serta perilaku sehat dan sportif.

Sekumpulan gerakan yang dilakukan dengan teratur dan terencana yang bertujuan merawat gerak, artinya olahraga bertujuan untuk menjaga dan meningkatkan keaktifan gerak (Giriwiyono \& Sidik, 2012). Olahraga juga dapat dijadikan sarana untuk menunjang prestasi, dengan penyediaan fasilitas yang baik serta pembinaan sedari dini, olahraga mampu mewadahi proses pengembangan potensi yang dimiliki masyarakat.Dari sekian banyak olahraga terdapat olahraga permainan yaitu bolabasket, bolavoli dan sepakbola. Di antara permainan olahraga yang paling menyita banyak perhatian dan minat yaitu olahraga sepakbola, adapun olahraga yang sejenis dengan sepakbola tetapi ukuran lapangan dan pemainnya diperkecil yaitu olahraga futsal.

Futsal ialah olahraga yang dilakukan secara beregu dan paling diminati oleh para olahragawan. Ada kepuasan tersendiri bagi mereka yang melakukan olahraga futsal, selain mampu menciptakan keasyikan dan juga kebersamaan bagaimana cara mereka bermain dengan berbagai perbedaan kemampuan tiap individu yang dijadikan menjadi satu tim untuk memenangkan pertandingan tersebut. Olahraga futsal sendiri tersusun atas dua tim yang saling berkompetisi. Setiap tim dalam permainan futsal beranggotakan 12 orang yang terdiri dari 5 orang pemain utama dan 7 orang pemain cadangan.

Menjamurnya olahraga futsal baik di daerah pelosok maupun kota ini merupakan fenomena dalam masyarakat. Terlebih karena olahraga futsal tidak terlalu membutuhkan banyak tempat untuk melakukan olahraga futsal serta waktu yang bisa dilakukan kapan saja, baik pagi, siang, sore, bahkan malam hari tanpa terganggu cuaca karena dapat dilaksanakan di dalam maupun luar ruangan.

Peminat olahraga futsal sendiri juga dari berbagai kalangan, tidak hanya anak-anak, pelajar, mahasiswa, selebritis, bahkanjuga para pejabatnegarajuga sangatmenggemari olahraga futsal tersebut. Banyak sekali manfaat olahraga futsal sendiri, selain menyehatkan badan, futsal juga dapat digunakan sebagai sarana rekreasi, mengusir stres, dan juga bisa untuk menyambung silaturahmi dengan para kolega. Bahkan selain menjadi sarana rekreasi, olahraga futsal sering dijadikan ajang turnamen baik antar pelajar ataupun mahasiswa.

Berdasarkan hasil observasi awal pada tanggal 15 Mei 2019 di SMAN 1 Srengat, sekolah tersebut memiliki sarana dan prasarana untuk olahraga futsal. Namun banyak faktor yang mempengaruhi minat para siswa untuk mengikuti ekstrakurikuler futsal, seperti kurangnya pengetahuan teknik dasar bermain futsal, jam atau waktu ekstrakurikuler yang tidak tepat atau motivasi dari dalam maupun luar diri siswa tersebut atau yang sering disebut motivasi ekstrinsik dan intrinsik. Kegiatan ekstrakurikuler di SMAN 1 Srengat sendiri berjalan lancar dan rutin, yaitu 3 kali dalam satu minggu pada hari Selasa, Jumat dan

Minggu, meskipun berjalan dengan rutin kehadiran para siswa yang mengikuti ekstrakurikuler tersebut tidak sepenuhnya hadir di setiap pertemuan, hasil observasi awal dari 
total 30 siswa yang terdaftar sebagai peserta ada 3-5 siswa yang tidak hadir di setiap pertemuan untukmengikuti ekstrakurikuler futsal di sekolah tersebut.

Berdasarkan penelitian terdahulu yang dilakukan oleh Ardiansyah (2016), menegaskan bahwasanya minat siswa dalam berpartisipasi dalam kegiatan ekstrakurikuler futsal sangat kurang mencapai 73,91\%. Sedangkan Arduta (2020), menyebutkan bahwa indikator rasa senang, dan ketertarikan siswa yang ikut serta dalam kegiatan ekstrakurikuler futsal menyumbang $36,05 \%$ dari faktor internal dan sebesar $63,9 \%$ berasal dari faktor eksternal yang meliputi indikator pelatih, lingkungan, fasilitas, dan keluarga. Hal tersebut secara tidak langsung mengisyaratkan bahwa faktor penentu besarnya minatsiswa dalam berpartisipasi pada kegiatan ekstrakurikuler ialah faktor eksternal.

Latar belakang masalah tersebut merupakan dasar yang digunakan peneliti untuk mengkaji tentang motivasi siswa-siswa SMA, futsal dengan penelitian "Survei Motivasi Siswa Dalam Mengikuti Kegiatan Ekstrakurikuler Futsal di SMA Negeri 1 Srengat Kabupaten Blitar".

\section{Metode}

Pada penelitian kali ini metode yang digunakan adalah metode kuantitatif deskriptif. Persamaan yang digunakan untuk menentukan besarnya minat dan motivasi siswa dalam bentuk persentase ialah dengan menggunakan persamaan berikut.

$P=\frac{f}{N} \times 100 \%$

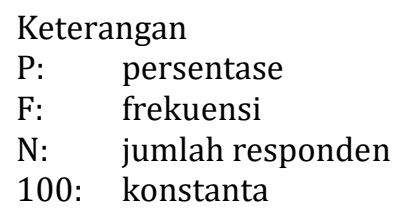

Data yang dihasilkan melalui kegiatan penelitian kemudian dianalisis menggunakan teknik analisis deskriptif dalam bentuk persentase. Pada Tabel 1 dibawah akan dijabarkan rincian kualifikasi analisis persentase dengan kriteria berikut.

Tabel 1. Kriteria Presentase Jawaban Responden

\begin{tabular}{ll}
\hline \multicolumn{1}{c}{ Presentase Jawaban } & \multicolumn{1}{c}{ Kualifikasi } \\
\hline $76 \%-100 \%$ & Baik \\
$56 \%-75 \%$ & Cukup \\
$40 \%-55 \%$ & Kurang Baik \\
$<40 \%$ & Kurang Sekali \\
\hline
\end{tabular}

Teknik pengukuran dengan menggunakan skala likert, tujuannya skala likert adalah mengukur presepsi individu atau kelompok mengenai kejadian sosial (Sugiyono, 2014). Pengisian angket sendiri dilakukan dengan cara memilih jawaban berikut, pilihan A jika sangat setuju mendapatkan nilai 4, B jika setuju mendapat nilai 3, C jika tidak setuju mendapat nilai 2, D jika sangat tidak setuju mendapat nilai 1. 


\section{Hasil dan Pembahasan}

\subsection{Hasil}

\subsubsection{Motivasi Intrinsik}

\subsubsection{Motivasi karena Adanya Minat dari Siswa}

Berdasarkan hasil pengolahan data melalui persamaan yang telah ditentukan, menunjukkan bahwa kategori motivasi intrinsik aspek minat siswa dalam berpartisipasi pada pelaksanaan ekstrakurikuler futsal dikategorikan dalam Tabel 2 berikut.

Tabel 2. Hasil Pengkategorian Tingkat Motivasi Intrinsik Siswa dalam Aspek Minat

\begin{tabular}{llcc}
\hline No & Kategori & Frekuensi & Persentase \\
\hline 1 & Baik & 16 & $53,3 \%$ \\
2 & Cukup & 14 & $46,7 \%$ \\
3 & Kurang Baik & 0 & $0 \%$ \\
4 & Kurang Sekali & 0 & $0 \%$ \\
Total & & 30 & $100 \%$ \\
\hline
\end{tabular}

Berdasarkan paparan data di atas diperoleh data berupa tingkat motivasi intrinsik dalam aspek minat siswa dalam berpartisipasi pada pelaksanaan ekstrakurikuler futsal di SMA 1 Srengat, meliputi 53,3\% siswa dengan total 16 siswa tergolong dalam kategori baik, sebesar $46,7 \%$ siswa ada 14 siswa yang termasuk dalam kategori cukup serta tidak terdapat siswa yang berada dalam kategori kurang baik dan kurang sekali.

\subsubsection{Motivasi karena Adanya Kepuasan}

Melalui hasil pengolahan data yang dilakukan diketahui kategori motivasi intrinsik aspek kepuasan dalam berpartisipasi pada kegiatan ekstrakurikuler futsal. Berikut hasil pengolahan data yang ditunjukkan pada Tabel 3 .

Tabel 3. Hasil Pengkategorian Tingkat Motivasi Intrinsik Siswa dalam Aspek Kepuasan

\begin{tabular}{llcc}
\hline No & Kategori & Frekuensi & Persentase \\
\hline 1 & Baik & 26 & $86,7 \%$ \\
2 & Cukup & 4 & $13,3 \%$ \\
3 & Kurang Baik & 0 & $0 \%$ \\
4 & Kurang Sekali & 0 & $0 \%$ \\
& Total & 30 & $100 \%$ \\
\hline
\end{tabular}

Berdasarkan paparan data di atas diperoleh bahwa tingkatan motivasi siswa dalam berpartisipasi pada pelaksanaan ekstrakurikuler futsal di SMA Negeri 1 Srengat pada aspek kepuasan $86,7 \%$ siswa dengan total 26 siswa berada dalam kategori baik, sebesar 13,3\% siswa dengan total 4 siswa berada pada kategori cukup dan tidak ada siswa yang berada dalam kategori kurang baik maupun kurang sekali. 


\subsubsection{Motivasi karena Adanya Pengetahuan}

Berdasarkan hasil pengolahan data yang dilakukan pengkategorian motivasi intrinsik aspek pengetahuan ketika berpartisipasi dalam kegiatan ekstrakurikuler futsal dapat dideskripsikan dalam data berbentuk tabel pada Tabel 4 .

Tabel 4. Hasil Pengkategorian Tingkat Motivasi Intrinsik Siswa dalam Aspek Pengetahuan

\begin{tabular}{llcc}
\hline No & Kategori & Frekuensi & Persentase \\
\hline 1 & Baik & 16 & $53,3 \%$ \\
2 & Cukup & 14 & $46,7 \%$ \\
3 & Kurang Baik & 0 & $0 \%$ \\
4 & Kurang Sekali & 0 & $0 \%$ \\
& Total & 30 & $100 \%$ \\
\hline
\end{tabular}

Berdasarkan uraian data di atas didapati bahwa tingkat motivasi intrinsik siswa dalam berpartisipasi pada kegiatan ekstrakurikuler futsal di SMA Negeri 1 Srengat pada aspek pengetahuan 53,3\% siswa dengan total 16 siswa tergolong dalam kategori baik, dan sebesar $46,7 \%$ siswa yaitu sebanyak 14 orang siswa tergolong dalam kategori cukup, dan tidak terdapat satu siswa pun yang berada dalam kategori kurang baik ataupun kurang sekali.

\subsubsection{Motivasi karena Adanya Perasaan}

Setelah dilakukan pengolahan data dapat diketahui penggolongan kategori motivasi intrinsik pada aspek perasaan dalam berpartisipasi pada kegiatan ekstrakurikuler futsal dapat dideskripsikan dalam bentuk tabel pada Tabel 5 .

Tabel 5. Hasil Pengkategorian Tingkat Motivasi Intrinsik Siswa dalam Aspek Perasaan

\begin{tabular}{llcc}
\hline No & Kategori & Frekuensi & Persentase \\
\hline 1 & Baik & 27 & $90 \%$ \\
2 & Cukup & 3 & $10 \%$ \\
3 & Kurang Baik & 0 & $0 \%$ \\
4 & Kurang Sekali & 0 & $0 \%$ \\
& Total & 30 & $100 \%$ \\
\hline
\end{tabular}

Berdasarkan rincian data di atas didapati bahwa tingkat motivasi instrinsik siswa dalam berpartisipasi pada pelaksanaan ekstrakurikuler futsal di SMA Negeri 1 Srengat pada aspek perasaan, sebagian besar siswa yaitu sebesar $90 \%$ dari keseluruhan jumlah siswa yaitu sebanyak 27 siswa yang kemudian dikategorikan dalam kondisi baik dan sebesar 3\% siswayang berjumlah 3 orang termasuk dalam kategori cukup dan tidak terdapat siswa yang termasuk dalam kategoru kurang baik maupun kurang sekali.

\subsubsection{Motivasi karena Adanya Bakat}

Hasil pengolahan data setelah dilakukan penghitungan menunjukkan kategori motivasi intrinsik pada aspek bakat saat berpartisipasi pada pelaksanaan ekstrakurikuler futsal di SMA Negeri 1 Srengat dapat divisualisasikan pada Tabel 6. 
Tabel 6. Hasil Pengkategorian Tingkat Motivasi Intrinsik Siswa dalam Aspek Bakat

\begin{tabular}{llcc}
\hline No & Kategori & Frekuensi & Persentase \\
\hline 1 & Baik & 11 & $36,4 \%$ \\
2 & Cukup & 19 & $63,3 \%$ \\
3 & Kurang Baik & 0 & $0 \%$ \\
4 & Kurang Sekali & 0 & $0 \%$ \\
& Total & 30 & $100 \%$ \\
\hline
\end{tabular}

Berdasarkan penjabaran data melalui tabel di atas menunjukkan bahwa tingkat motivasi intrinsik siswa dalam berpartisipasi pada pelaksanaan ekstrakurikuler futsal di SMA Negeri 1 Srengat pada aspek bakat ialah sebesar $36,4 \%$ siswa yaitu sebanyak 16 siswa yang dikategorikan baik dan sebesar $63,3 \%$ siswa yaitu sejumlah 19 orang siswa berada dalam kategori cukup dan tidak terdapat satu siswa yang berada dalam kategori kurang baik maupun kurang sekali.

\subsubsection{Motivasi Ekstrinsik}

\subsubsection{Motivasi karena Adanya Pujian}

Berdasarkan hasil pengolahan data didapati pengkategorian motivasi intrinsikpadaaspek adanya pujian dalam berpartisipasi pada kegiatan ekstrakurikuler futsal. Data tersebut kemudian dapat divisualisasikan dalam Tabel 7.

Tabel 7. Hasil Pengkategorian Tingkat Motivasi Intrinsik Siswa dalam Aspek Pujian

\begin{tabular}{llcc}
\hline No & Kategori & Frekuensi & Persentase \\
\hline 1 & Baik & 4 & $13,3 \%$ \\
2 & Cukup & 24 & $80 \%$ \\
3 & Kurang Baik & 2 & $6,7 \%$ \\
4 & Kurang Sekali & 0 & $0 \%$ \\
& Total & 30 & $100 \%$ \\
\hline
\end{tabular}

Berdasarkan penjabaran data di atas didapati bahwa kategori motivasi siswa dalam berpartisipasi pada pelaksanaan ekstrakurikuler futsal di SMA Negeri 1 Srengat dalam aspek pujian 13,3\% yaitu sejumlah 4 orang yang dikategorikan baik, dan $80 \%$ peserta didik dengan sejumlah 24 siswa masuk dalam kategori cukup dan yang terakhir sebesar 6,7\% yaitu sebanyak 2 siswa termasuk dalam kategori kurang baik namun tidak terdapat siswa yang berada dalam kategorikurang sekali.

\subsubsection{Motivasi karena Adanya Penghargaan}

Berdasarkan hasil pengolahan data didapati pengkategorian motivasi intrinsikpadaaspek penghargaan dalam berpartisipasi pada kegiatan ekstrakurikuler futsal. Datatersebut kemudian dapat divisualisasikan dalam Tabel 8. 
Tabel 8. Hasil Pengkategorian Tingkat Motivasi Intrinsik Siswa dalam Aspek Penghargaan

\begin{tabular}{llcc}
\hline No & Kategori & Frekuensi & Persentase \\
\hline 1 & Baik & 16 & $53,3 \%$ \\
2 & Cukup & 14 & $46,7 \%$ \\
3 & Kurang Baik & 0 & $0 \%$ \\
4 & Kurang Sekali & 0 & $0 \%$ \\
& Total & 30 & $100 \%$ \\
\hline
\end{tabular}

Berdasarkan penjabaran data di atas didapati bahwa kategori motivasi siswa dalam berpartisipasi pada pelaksanaan ekstrakurikuler futsal di SMA Negeri 1 Srengat dalam aspek penghargaan sebesar 53,3\% siswa yaitu sejumlah 16 siswa dikategorikan baik, sebesar 46,7\% siswa yaitu sebanyak 14 siswa tergolong pada kategori cukup serta tidak ada yang termasuk dalam kategori kurang baik maupun kurang sekali.

\subsubsection{Motivasi karena Adanya Persaingan}

Berdasarkan hasil pengolahan data didapatipengkategorian motivasi intrinsikpadaaspek persaingan dalam berpartisipasi pada kegiatan ekstrakurikuler futsal. Data tersebut kemudian dapat divisualisasikan dalam Tabel 9.

Tabel 9. Hasil Pengkategorian Tingkat Motivasi Intrinsik Siswa dalam Aspek Persaingan

\begin{tabular}{llcc}
\hline No & Kategori & Frekuensi & Persentase \\
\hline 1 & Baik & 18 & $60 \%$ \\
2 & Cukup & 12 & $40 \%$ \\
3 & Kurang Baik & 0 & $0 \%$ \\
4 & Kurang Sekali & 0 & $0 \%$ \\
& Total & 30 & $100 \%$ \\
\hline
\end{tabular}

Berdasarkan penjabaran data di atas didapati bahwa kategori motivasi siswa dalam berpartisipasi pada pelaksanaan ekstrakurikuler futsal di SMA Negeri 1 Srengat dalam aspek persaingan $60 \%$ siswa yaitu sejumlah 18 orang dikategorikan baik dan sebesar 40\% siswa yaitu sejumlah 12 siswa tergolong dalam kategori cukup dan tidak ada yang termasuk dalam kategori kurang baik maupun kurang sekali.

\subsubsection{Motivasi karena Adanya Lingkungan}

Berdasarkan hasil pengolahan data didapatipengkategorian motivasi intrinsikpadaaspek lingkungan dalam berpartisipasi pada kegiatan ekstrakurikuler futsal. Data tersebut kemudian dapat divisualisasikan dalam Tabel 10.

Tabel 10. Hasil Pengkategorian Tingkat Motivasi Intrinsik Siswa dalam Aspek Lingkungan

\begin{tabular}{llcc}
\hline No & Kategori & Frekuensi & Persentase \\
\hline 1 & Baik & 10 & $33,3 \%$ \\
2 & Cukup & 16 & $53,3 \%$ \\
3 & Kurang Baik & 4 & $13,3 \%$ \\
4 & Kurang Sekali & 0 & $0 \%$ \\
& Total & 30 & $100 \%$ \\
\hline
\end{tabular}


Berdasarkan paparan data di atas diperoleh bahwa tingkat motivasi intrinsik siswa yang mengikuti pelaksanaan ekstrakurikuler futsal di SMA Negeri 1 Srengat dalam aspek lingkungan 33,3\% siswa yaitu sebanyak 10 orang dikategorikan baik, sebesar 53,3\% siswa yaitu sebanyak 16 orang siswa masuk dalam kategori cukup, sebesar $13,3 \%$ siswa yaitu sebanyak 4 orang masuk dalam kategori kurang baik dan tidak ada peserta dalam kategori kurang sekali.

\subsubsection{Motivasi karena Adanya Tuntutan dan Hukuman}

Berdasarkan hasil pengolahan data didapati pengkategorian motivasi intrinsik pada aspek tuntutan dan hukuman dalam berpartisipasi pada kegiatan ekstrakurikuler futsal. Data tersebut kemudian dapat divisualisasikan dalam Tabel 11.

\section{Tabel 11. Hasil Pengkategorian Tingkat Motivasi Intrinsik Siswa dalam Aspek Tuntutan} dan Hukuman

\begin{tabular}{llcc}
\hline No & Kategori & Frekuensi & Persentase \\
\hline 1 & Baik & 12 & $40 \%$ \\
2 & Cukup & 12 & $40 \%$ \\
3 & Kurang Baik & 4 & $13,3 \%$ \\
4 & Kurang Sekali & 2 & $6,7 \%$ \\
& Total & 30 & $100 \%$ \\
\hline
\end{tabular}

Berdasarkan paparan data di atas diperoleh bahwa tingkat motivasi intrinsik peserta yang mengikuti pelaksanaan ekstrakurikuler futsal di SMA Negeri 1 Srengat dalam aspek tuntutan dan hukuman $40 \%$ siswa yaitu sebanyak 12 orang dikategorikan baik, sebesar $40 \%$ siswa yaitu sebanyak 12 orang siswa masuk dalam kategori cukup, sebesar 13,3\% siswa yaitu sebanyak 4 orang masuk dalam kategori kurang baik serta sebesar $6,7 \%$ siswa yaitu sejumlah 2 orang siswa termasuk dalam kategori kurang sekali.

\subsection{Pembahasan}

Pada dasarnya motivasi merupakan keadaan orang yang mendorong dirinya dalam melaksanakan suatu kegiatan tertentu, hal tersebut dilakukan atas dasar keinginan dalam mencapai suatu tujuan. Motif merupakan suatu kekuatan dalam diri masing-masing pribadi untuk melakukan sebuah aktivitas. Dorongan yang muncul dalam diri seseorang untuk bertingkah laku dikenal dengan motivasi. Dengan begitu tingkah atau pola perilaku seseorang umumnya didasari atas keberadaan motivasi yang mengandung motivasi yang mendasarinya (Singgih, 2008).

Motivasi pada dasarnya dibedakan menjadi dua hal yaitu motivasi intrinsik dan ekstrinsik (Dimyati, 2010). Motivasi intrinsik merupakan kemauan dalam diri seseorang untuk bertindak yang muncul dengan adanya faktor penggerak dalam diri seorang individu. Aspek-aspek yang dipakai untuk mengukur motivasi intrinsik adalah minat. Minat merupakan suatu rasa ketertarikan yang ada pada diri seseorang ketika menjalankan aktivitas dan tanpa adanya tekanan (Sardiman, 2009). Minat dalam penelitian ini tercermin dalam ketertarikan dan partisipasi siswa ketika mengikuti kegiatan ekstrakurikuler futsal. Dimana siswa biasanya datang sebelum jam latihan dimulai, berlatih terlebih dahulu sebelum adanya instruksi, bersemangat dalam melaksanakan ekstrakurikuler futsal, membantu pelatih menyiapkan peralatan futsal, dan selalu membawa perlengkapan penunjang dengan lengkap. 
Aspek kedua dalam mengukur motivasi intrinsik adalah kepuasan yang merupakan salah satu penggerak motivasi intrinsik, dimana siswa akan merasakan puas ketika telah mencapai hasil dalam suatu kegiatannya (Prayitno, 2004). Kepuasan dapat diukur menggunakan seberapa besar siswa dapat memahami materi yang diberikan dan seberapa senang siswa dalam menjalankan kegiatan ekstrakurikuler futsal. Dalam hal ini siswa akan merasa senang ketika dapat melakukan contoh yang diberikan pelatih, siswa merasa tidak jenuh, siswa senang ketika terlibat dalam permainan menarik yang diberikan oleh pelatih, siswa merasa senang ketika ditunjuk sebagai instruktur untuk teman-temannya dan peserta akan lebih bersemangat ketika mudah dalam memahami materi yang diberikan.

Aspek ketiga yaitu pengetahuan yang mana aspek ini memiliki tujuan untuk menjadikan seseorang agar menjadi pribadi yang lebih terdidik dan memiliki wawasan luas dalam bidang tertentu. Aspek ini tercermin saat siswa menunjukkan rasa keingintahuan akan suatu hal, dan berusaha mengasah keterampilannya. Dalam hal ini siswa telah mengetahui manfaat ketika ia mengikuti kegiatan futsal, ia berusaha mencari pengetahuan tentang futsal melalui media internet dan bertanya kepada pelatihnya, siswa berusaha untuk melatih dirinya ketika ia mengalami kesulitan dalam mempraktikkan suatu materi.

Aspek keempat yaitu perasaan dimana aspek ini memiliki hubungan dengan perubahan energi secara internal yang ditunjukkan dengan adanya perasaan seseorang. Aspek ini dapat diukur menggunakan seberapa besar keinginan siswa dan rasa suka siswa ketika mengikuti ekstrakurikuler futsal. Siswa merasa senang ketika ia dapat menguasai teknik baru yang diberikan, mempelajari materi yang diberikan dengan sungguh-sungguh, siswa merasa senang jika dapat menyalurkan hobiyang ia sukai.

Aspek kelima dalam penelitian ini ialah bakat yang merupakan suatu keterampilan alami yang bersumber dari dalam diri masing-masing orang. Bakat dapat diukur menggunakan indikator prestasi dan pengetahuan akan bakat yang terdapat dalam dirinya. Dalam hal ini siswa yang telah memiliki prestasi akan berusaha mengembangkan keterampilannya dengan mengikuti ekstrakurikuler futsal, siswa ingin berprestasi ketika mengikuti kegiatan ekstrakurikuler futsal, siswa akan mulai berlatih sesuai dengan kemampuan yang dimiliki, siswa telah mengetahui bakatnya dan akan mengembangkan bakatnya tersebut dengan mengikuti ekstrakurikuler futsal.

Motivasi Ekstrinsik merupakan motif yang akan aktif dan berfungsi jika telah mendapatkan rangsangan dari luar (Uno, 2011). Tidak hanya itu, motivasi ekstrinsik dapat diartikan dorongan atas tindakan seseorang atau individu dan berasal dari luar perbuatan yang dikerjakan, hal tersebutterlihat saatterdapatstimulus dari luar. Motivasi ekstrinsik dapat diukur menggunakan aspek pujian dimana siswa akan mendapatkan suatu dukungan yang positif ketika ia telah berhasil mencapai suatu kinerja dengan baik. Biasanya pujian tersebut akan siswa dapatkan dari orang tua, guru, bahkan orang terdekatnya. Dalam hal ini siswa akan merasa senang saat mendapatkan pujian dari pelatih futsalnya, siswa merasa mendapatkan dukungan dengan diberikannya applause ketika ia berhasil menyelesaikan tantangan yang diberikan, siswa mendapat pujian dari orang tua ketika meraih sebuah prestasi, dan siswa mendapatkan pujian dari temannya ketika ia dapat melakukan tugas yang diterima dengan benar.

Aspek selanjutnya adalah penghargaan yang merupakan suatu bentuk hadiah atau tolak ukur dalam memunculkan motivasi dari siswa dan dijadikan sebagai penguat tingkah laku siswa. Penghargaan diberikan ketika siswa telah mencapai suatu prestasi dan hasil belajar dengan baik. 
Hal ini tercermin dalam pemberian apresiasi oleh pelatih ketika siswa rajin mengikuti ekstrakurikuler futsal, ingin mendapatkan penghargaan dari sekolah ketika ia dapat mewakili sekolah dalam perlombaan futsal, mendapatkan penilaian sikap afektif yang baik oleh pelatih ketika siswa aktif dalam kegiatan ekstrakurikuler futsal, dan mendapatkan apresiasi dari pelatih ketika selalu membantu mengurus peralatan yang dibutuhkan saat futsal.

Pada penelitian ini, aspek yang akan dibahas adalah persaingan. Persaingan merupakan sebuah wujud kompetisi dan akan memicu individu belajar dan mengkomparasikan antara prestasi yang didapatnya secara pribadi dengan prestasi yang telah dicapai oleh pribadi lainnya. Aspek ini dapat diukur melalui indikator persaingan hasil belajar dan persaingan saat games berlangsung. Hal ini tercermin dalam kegiatan dimana siswa akan berusaha untuk mendapatkan apresiasi yang lebih baik daripada temannya, siswa akan bersungguh-sungguh saat menerima materi futsal agar dapat mewakili sekolah saat terdapat kejuaraan, pelatih akan selalu menanamkan jiwa kompetisi agar siswa dapat mencapai hasil belajar yang memuaskan, pelatih selalu memberikan permainan ketika pemberian materi futsal dan memberikan hadiah bagi pemenangnya, dan selalu ada permainan yang menantang dalam setiap materi sehingga lebih menarikuntuk diikuti.

Aspek selanjutnya adalah lingkungan yang dapat diukur menggunakan indikator fasilitas yang dimiliki, teman, dan keluarga. Aspek ini tercermin dalam siswa tertarik untuk mengikuti ekstrakurikuler karena lingkungan pembelajaran yang nyaman, fasilitas yang diperlukan untuk mengikuti ekstrakurikuler futsal sudah tertunjang dengan baik oleh orang tua dan sekolahnya, siswa lebih merasa antusias untuk mengikuti ekstrakurikuler futsal ketika banyak teman yang bersemangat untuk mengikutinya, siswa bersemangat mengikuti ekstrakurikuler karena saudaranya menjadi seorang atlet, dan siswa bercita-cita untuk menjadi olahragawan karena ayahnya adalah seorang olahragawan.

Aspek yang terakhir adalah tuntutan dan hukuman yang merupakan suatu bentuk dukungan negatif yang harus diberikan dengan cara tepat dan bijaksana agar dapat menjadi sebuah alat motivasi (Sardiman, 2009). Hal ini dapat diukur melalui tuntutan dan hukuman yang diberikan kepada siswa. Tercermin dalam kegiatan saat siswa mendapatkan nilai yang jelek ketika tidak mengikuti ekstrakurikuler, siswa dituntut untuk memahami dan menguasai materi dengan baik, siswa akan ditegur oleh pelatih ketika ia tidak menghadiri, siswa tidak diperbolehkan untuk mengikuti pelaksanaan ekstrakurikuler futsal jika ia datang dengan terlambat tanpa alasan yang jelas, dan siswa tidak diperbolehkan untuk mengikuti materi ketika sebelumnya ia tidakmempelajari di rumah.

Adapun masalah yang diteliti pada topik penelitian ini "Motivasi Siswa dalam Mengikuti Kegiatan Ekstrakurikuler futsal di SMA Negeri 1 Srengat Kabupaten Blitar". Penelitian ini didukung dengan penelitian terdahulu yang dilakukan oleh Nugroho (2010) "tidak terdapat perbedaan antara tingkat motivasi intrinsik dan ekstrinsik peserta yang melaksanakan ekstrakurikuler futsal di SMPN 3 Kota Malang. Kemudian, penelitian oleh Hardiansyah (2016) tingkat motivasi intrinsik peserta yang melaksanakan ekstrakurikuler futsal MTS Wahid Hasyim memiliki kategori baik dengan persentase $81,83 \%$, sedangkan motivasi ekstrinsik memiliki kategori gagal dengan persentase 38,14\%. Sedangkan penelitian Purnomo (2010) "tidak terdapat perbedaan yang signifikan antara tingkat motivasi intrinsik dan ekstrinsik kegiatan ekstrakurikuler pencak silat di SMAN 1 Kabupaten Mojokerto". Selanjutnya penelitian Ade dan Nanang (2013) menyatakan bahwa motivasi yang paling dominan pada siswa SMA Dr. Soetomo 
Surabaya dalam mengikuti futsal ekstrakurikuler terdapat pada motivasi intrinsik dibandingkan motivasi ekstrinsik.

\section{Simpulan}

Berdasarkan dari seluruh data yang telah dipaparkan sebelumnya, bahwa terdapat dua jenis motivasi siswaSMA Negeri1 Srengat Blitar dalam mengikuti kegiatan ekstrakurikuler futsal yakni motivasi intrinsik dan ekstrinsik. Motivasi yang paling berpengaruh terhadap keikutsertaan siswa SMA Negeri 1 Srengat Blitar dalam melaksanakan kegiatan ekstrakurikuler futsal ialah motivasi intrinsik dengan indikator perasaan. Perasaan disini memiliki makna bahwa adanya rasa senang yang secara tidak sadar direspon oleh tubuh karena melaksanakan kegiatan ekstrakurikuler futsal dan perasaan ini timbul akibat siswa dapat melakukan teknik futsal yang telah diajarkan sebelumnya. Sedangkan untuk motivasi ekstrinsik yang paling memberikan pengaruh terhadap siswa adalah karena adanya lingkungan. Hal ini terlihat dari lingkungan yang nyaman dapat membuat siswa menjadi enjoy dalam mengikuti ekstrakurikuler futsal. Selain itu, dengan ditunjangnya sarana dan prasarana yang memadai juga dapat membuat siswa menjadi termotivasi untuk mengikuti kegiatan tersebut.

\section{Daftar Rujukan}

Arikunto, S. (2010). Prosedur Penelitian Suatu Pendekatan Praktik. Jakarta: PT Rineka Cipta.

Dimyati. (2010). Belajar dan Pembelajaran. Jakarta: PT. Rineka Cipta.

Giriwiyono, S \& Sidik, Z. (2012). Ilmu Kesehatan Olahraga. Bandung: PT . Remaja Rosdakarya.

Hardiansyah. (2016). Survei Motivasi Siswa MTs Wahid Hasyim 02 Desa Kucur Kecamatan Dau Kabupaten Malang Dalam Mengikuti Ekstrakurikuler Futsal. Skripsi Tidak Diterbitkan. Malang:FIK UM.

Hasbullah, M. (2016). Kebijakan Pendidikan. Jakarta: PT Raja Grafindo Persada.

Irawan, A. (2009). Penyusunan Instrumen Tes Keterampilan Teknik Futsal pada Mahasiswa DKI Jakarta. Skripsi. Jakarta: FIK UNJ.

Jaya, A. (2008). Futsal. Yogyakarta: Pustaka Timur.

Komarudin, (2015). Psikologi Olahraga. Bandung: PT Remaja Rosdakarya Offset

Kompri. (2015). Manajemen Pendidikan : Komponen - komponen Elementer Kemajuan Sekolah. Yogyakarta: ArRuzzMedia

Prayitno, E. (2004). Motivasi Dalam Belajar. Jakarta. Departemen Pendidikan dan Kompri.

Lhaksana J. \& Ishak, P. (2008). Inspirasi dan Spirit Futsal. Jakarta: Raih Asa Sukses

Lhaksana, J. (2011). Taktik dan Strategi Futsal Modern. Jakarta: Be Champion.

Mu'arifin. (2012). Dasar-Dasar Pendidikan Jasmani dan Olahraga. Malang: Universitas Negeri Malang (UM Press).

Nugroho, S. S. (2010). Survei Tentang Motivasi Siswa Peserta Kegiatan Ekstrakurikule Futsal di SMP Negeri 3 Kota Malang. Skripsi Tidak Diterbitkan. Malang:FIK UM.

Prihatin, E. (2017). Menejemen Siswa. Bandung: Alfabeta.

Purnomo, E. A. (2010). Survei Tingkat Motivasi Siswa Dalam Kegiatan Ekstrakurikuler Pencak Silat Tahun Ajaran 2010/2011 di UPTSP SMA Negeri 1 Kutorejo Kabupaten Mojokerto. Skripsi Tidak Diterbitkan. Malang:FIK UM.

Santrock, J. W. (2011). Psikologi Pendidikan. Jakarta: Salemba Humanika.

Singgih, G. D. (2008). Psikologi Olahraga Prestasi. Jakarta: PT BPK Gunung Mulia.

Siswanto, W., dkk. (2018). Survei Minat dan Motivasi Bermain Futsal Siswa SMK Negeri 4 Makasar.

Sopiatin, P. (2010). Manajemen Belajar Berbasis Kepuasan Siswa. Cilegon: Ghalia Indonesia.

Sudianto, M. (2005). Pendidikan Jasmani. Malang: Universitas Negeri Malang. 
Sport Science and Health, 3(8), 2021, 574-585

Sukirno. (2010). Belajar Bermain Futsal. Depok: CV. Arya Duta

Undang-Undang Republik Indonesia Nomor 20 Tahun 2003 tentang Sistem Pendidikan Nasional .(online), (http://kelembagaan.ristekdikti.go.id)

Uno, H. B. (2011). Teori Motivasi dan Pengukurannya. Jakarta: PT. Bumi Aksara.

Winarno, M. E. (2013). Metodologi Penelitian Dalam Pendidikan Jasmani. Malang: Universitas Negeri Malang

Yuliasari, Ade \& Nanang. (2013). Peran Dominan Motivasi Intrinstik dan Motivasi Ekstrinsik Siswa dalam Mengikuti Kegiatan Ekstrakurikuler Futsal. Jurnal Pendidikan Olahraga dan Kesehatan, 1 (2), 314-317. 